\section{Health of Tanganyika}

THE chief points of interest in the recently published annual report for 1939 of the Medical Department of Tanganyika Territory are the plans for the development of $a$ native medical, nursing and public health service. The War has interfered with plans for nutritional investigations and relief for deficiencies, although a start has been made. As regards the incidence of various diseases the most important facts are as follows : the discovery of two fresh foci of sleeping sickness (663 cases with 184 deaths), cerebrospinal fever (2,183 cases with 237 deaths), the discovery of a plague-infected rat, and an investiga. tion of smallpox. 248,533 cases of infectious and parasitic diseases were reported from various Govern. ment institutions. The most frequent diseases were as follows in the order named: yaws, malaria, syphilis, ankylostomiasis, gonorrhœa, schistosomiasis and tuberculosis. The population of Tanganyika in 1939 was : Europeans 9,165, Asiatics 33,974, and Africans 5,217,345.

\section{The Completed Map of North East Land}

AlrнобGH North East Land, the most easterly island of the Spitsbergen group, was known to the seventeenth-century whalers, it was relatively unexplored until some twenty years ago, except for an attempt by A. E. Nordenskjöld in 1873. The modern survey, begun by the Oxford University Expedition of 1924, was virtually completed by the Oxford Expedition of 1935-36, though some important work was done by the Swedish-Norwegian Expedition of 1931. The map published in the Geographical Journal of October 1937 is now revised in some minor and one major point by a new map in the Geographical Journal of October 1941 (A. R. Glen, "The Latest Map of North East Land"). This map makes use of the Norwegian aerial surveys of North East Land in 1938 which are not now accessible, and it shows one remarkable change. In the south a great lobe of the South Ice has overridden the coast on a thirteen-mile front and pushed ten miles out to sea. Recent investigations show that the ice of North East Land is in the main in retreat : small ice-free areas have been found on the east coast. This advance is probably purely local, and Mr. Glen suggests that it may be due to a tectonic disturbance or some internal glacial cataclysm. The whole surface of the ice lobe is heavily crevassed.

\section{National Central Library}

THe twenty-fifth annual report of the executive committee of the National Central Library for the year 1940-41 refers again to the special war work of the Library for Government departments, research stations and industrial concerns, as well as to the service organized in co-operation with the county libraries and the Scottish Central Library for Students, for the supply of educational books to men serving in the Army in all parts of the British Isles. A similar service has been given to men serving in the Royal Air Force, and the Library has also been able to assist men serving in the Royal Navy and in the Mercantile Marine through the agency of the Seafarers' Education Service. At the request of the Home Office, the Library has organized, with the assistance of the local urban or county libraries concerned, a service for the supply of educational books to aliens in internment camps. The Library has acted as agent of the American Library Association's Committee on International Relations in connexion with the distribution of American books and periodicals to men serving in the British Forces at home and overseas. With the assistance of the British Council, the Library has also been instrumental in supplying books in their own language to sailors, soldiers, airmen and civilian refugees from Czechoslovakia, Greece, Holland, Poland and other Allied countries now in the British Isles.

When the Treasury grant in aid to the Library for the year 1940 -4l was reduced from $£ 4,800$ to $£ 3,500$, the trustees of the Rockefeller Foundation made an emergency grant of 8,500 dollars for the year 1940-4I, and the Foundation has continued to provide money for the upkeep of the Bureau of American Bibliography. The trustees of the Carnegie United Kingdom Trust continued their grant of $£ 4,000$. The total number of books issued during the year decreased from 50,611 to 39,420 , issues to university libraries being 2,433 as against 3,046 in the previous year; of these, 1,100 were supplied by university libraries themselves.

\section{Museum of the Royal College of Surgeons}

THE scientific report of the Royal College of Surgeons for the year 1940-41 states that the Museum and store rooms were hit during an air raid, ineendiaries increased the damage, falling girders broke up the basement below, and heavy rain the following days drenched the exposed specimens. The loss, though serious, was not complete. In the anatomical series 1,207 specimens survived out of 2,569. In the osteological series, out of 1,655 Hunterian specimens only 94 were saved, and 6,209 of 15,545 College specimens. On the other hand, the whole of the odontological series was saved. Nearly half the 5,400 Hunterian physiological specimens escaped, but only 2,026 of the 14,850 College specimens in this series. Of the human and comparative teratological specimens only 23 of 170 Hunterian specimens remain, but the College specimens have largely survived. The better part of the Hunterian pathological series remains, but the College specimens have been reduced to about a fifth, and the whole of the Townbee and Strangeways collection has gone; the Army Medical War Collection has been reduced from 3,000 to 100 . All the mummified specimens and the historical collection are lost, and the instruments collection has been reduced from 2,500 to 2,000. The zoological and anthropological pictures have survived, including Tonks's war pictures. The total loss of specimens amounts to 39,259 out of 65,827 .

\section{Vacation Apprenticeship Scheme}

THE value of practical training, and of a close linkage with industrial practice during the undergraduate years, is receiving more and more recognition in scientific academic circles to-day. This is the case, not only in the engineering faculties, but also in branches of pure and applied science-chemistry, physics, and even biology. That this is also appreciated and valued by industrial firms themselves is apparent from the steadily growing success that has attended the Vacation Apprenticeship Scheme carried on by the Imperial College Union for the benefit of students of all departments in the Imperial College of Science and Technology. From its inception seven years ago, the scheme has shown a steady record of progress in spite of the uncertainties of the 
past iow years. In the summer of 1941 , for example, 124 firms accommodated 181 students, granting them the opportunity to receive valuable experience in many of the experimental and production processes. The reports of the firms and of the students show how well and how smoothly the scheme is working. It is significant in this connexion that since the inception of the scheme, the average earnings per student reached its poak in 1941 .. I) vacution, July-September, 1942, more than three hundred students of the Imperial College will be available for varying periods of from six to eight weeks, and there is evidence that the co-operation of industry is likely to expand with this growing demand for absorption.

\section{The Linnean Society of London}

'THE Linnean Society of London is now holding some of its meetings (those of zoological interest) in conjunction with the Zoological Society of London. The Society has decided to invite by name botanists and zoologists who are refugees in Great Britain to attend the genoral meetings of the Socioty. If, therefore; any such botanists or zoologists will make application to the Assistant Secretury, the Council will consider the issue of invitations to attend the meetings.

The following discussions are being arranged by the Society : (1) "The biogeogruphic division of the Indo-Australian Archipelago; criticism of the Wal. lace and Webor lines, and of any other dividing lines, with an attempt to obtain uniformity in tho names used for the divisions". 'The subjoct will be introdueed by an account of the geological history and climates of the Archipelago, by Mr. J. B. Scrivenor, lately director of the Geological Survey, Federated Malay States (in April); (2) "Time, temperatur" and humidity in the germination of seeds", to follow an address on "Recent work on germination", by Dr. M. A. H. 'Tincker (on May 14) ; (3) "Intertidal zonation of animals and plants", introduced by an address on "The causes of the zonation of animals and algæ between tide marks", hy Prof. T. A. Stephenson (on June 18).

\section{Broadcasts on the Sub-visible Universe}

A series of twelve talks under the title "Science Lifts the Veil", which deals with the structure of matter, is being given on Mondays in the Empire programme of the British Broadcasting Corporation. The talks, which were introduced by Sir William Bragg on January 5, have been arranged with the advice and assistance of the Science Committee of the British Council. Sir William Bragg explained the ides and significance of the theme. He pointed out that the growth of science and of its power is largely due to an increasing ability to see or recognize smaller and still smaller things. The range of the unaided eye is limited, and it has been natural to ignore what cannot be seen. 'The microscope opened the way to more thorough knowledge; other means have been developed in succession. As each fresh veil has been lifted from the regions of the subvisible universe, a new range of knowledge has been revealed, and this has in many cases provided mankind with new powers over materials, life and health. The talks; which are being given by leading men of science, will explain the revelations that have come with the magnifying glass and the microscope, $\mathrm{X}$-rays, the electron-microscope and other aids to he exploration of the small. Their effect on the many forms of science, on those which deal with natural processes, the living cell, bacteria, health and disease, on those which deal with human construction, dyes, drugs, alloys, textiles and the materials handled every day, on those sciences which are concerned with the production, preservation, and the use of food, will be explained by men who have themselves taken part in the conquest of this subvisible universe.

\section{Hill Sheep Farming}

THE Agricultural Improvement, ('ouncil for England and Wales has set up a Committee "to investigate the present position of hill and upland sheep farming in England and Wales and in the light of modern scientific knowledge to suggest moasures that might be taken to improve the condition of hill and upland grazings, the health and hardiness of sheep stocks and systems of stock. ing and management". The Committee is constituted as follows: Lord De La Warr (chairman); Mr. J. C. F. Fryer, Mr. Moses Griffith, grassland adviser at the Plant-breeding Station, Aberyst wyth ; Mr. David Iewis ; Dr. R. F. Montgomerie; Prof. G. W. Robinson, professor of agricultural chemistry in the lnivorsity ('ollege of North Wales, Bangor; Dr. R. W. Wheldon, lecturer in agriculture at King's College, Newcastle-uponTyne; Mr. W. Wilson. Mr. D. H. Dinsdale, adviser in agricultural oconomies, King's College, Newcastle-on-Tyne, will act as technical secretsry to the Committee, and tho administrativo secretary will be Mr. J. H. Banbury, of the Ministry of Agriculture and Fisheries, Lindum Hotel, St. Annes-onSer, Lancs.

\section{Announcements}

Sir. John Russeil, director of the Rothamsted Experimental Station, has been appointed adviser to the Soviet Relations Branch of the Ministry of Information. During his well-known researches in agricultural science; Sir John has come into close contact with Soviet men of science and has travelled widely in the U.S.S.R.

Mr. J. K. Ross has been appointed assistant conservator of forests. Sierra Leone, in the Colonial Service.

Prof. ERwin PAYR, emeritus professor of surgery at Leipzig University, has been awarded the Goethe Medal for art and science.

To meet urgent needs, some of them arising from the War, four new teaching departments havo been set up at Leeds General Infirmary, dovoted respectivoly to thoracic surgery, physiotherapy, radiography and radiotherapv. and diototics.

The loard of Education announces that the scheme of State bursaries in science, tenable at univorsities and certain technical colleges, carrying fees and main tenance allowances, which was instituted last year to meet the demand for technical officers for the Armed Forces and for war industry, is being continued in 1942. Bursaries will bo awarded as last year in engineering, physics-with-radio, and chemistry. Full particulars are being sent to the headmasters and headmistresses of secondary and public achools. 